\title{
Corpus
}

\section{Much Ado About Nothing? On the Categorial Status of et and ne in Medieval French}

Michael Zimmermann et Georg A. Kaiser

\section{(2) OpenEdition}

1 Journals

\section{Édition électronique}

URL : http://journals.openedition.org/corpus/1941

DOI : $10.4000 /$ corpus. 1941

ISSN : 1765-3126

\section{Éditeur}

Bases; corpus et langage - UMR 6039

\section{Édition imprimée}

Date de publication : 1 novembre 2010

Pagination : 265-290

ISSN : 1638-9808

\section{Référence électronique}

Michael Zimmermann et Georg A. Kaiser, « Much Ado About Nothing? On the Categorial Status of et and ne in Medieval French », Corpus [En ligne], 9 | 2010, mis en ligne le 06 juillet 2011, consulté le 07 septembre 2020. URL : http://journals.openedition.org/corpus/1941 ; DOI : https://doi.org/10.4000/ corpus. 1941 


\title{
Much Ado About Nothing? On the Categorial Status of $e t$ and $n e$ in Medieval French ${ }^{1}$
}

\author{
Michael ZIMMERMANN \\ Georg A. KAISER \\ Universität Konstanz
}

\section{Introduction}

When syntactically annotating a text corpus from an earlier stage of some language, one is confronted with the task of determining the categorial status of the elements encountered. This task can become arduous when some element seems to resist a clear-cut categorial assignment. In this case, one sees oneself in principle confronted with the choice between a 'consistent' approach (assignment of a unique category) and an 'inconsistent' approach (assignment of various categories). Often, the (theory-induced) adoption of either approach proves to be problematic insofar as the categorial status of an element within a given text corpus is not (entirely) transparent and plausible. What is more, the existence of different approaches to one and the same element hinders the general comparability and reliability of corpus analyses.

A prime case in point involves the two Medieval French ${ }^{2}$ elements et and ne. Many researchers opt for a consistent approach and consider, irrespective of the syntactic context in which they occur, et to be a coordinating conjunction, meaning 'and', and ne, 'not', as the atonic clitic counterpart of the

1 We would like to express our warmest thanks to Bruce Mayo, Judith Meinschaefer, and Nikolaus Schpak-Dolt as well as to Maialen Iraola and Stefano Quaglia for their helpful and insightful comments.

2 By the term 'Medieval French', we refer to the periods of Old French $\left(8^{\text {th }}\right.$ $13^{\text {th }}$ century) and Middle French $\left(14^{\text {th }}-16^{\text {th }}\right.$ century).

Corpus $n^{\circ} 9$ «La syntaxe de corpus / Corpus Syntax » (2010), 265-290 


\section{ZIMMERMANN, G. A. KAISER}

adverbial non. This approach implies the analysis of the two elements at issue as non-constituents. ${ }^{3}$ Other researchers adopt an inconsistent approach, assuming that $e t$ and ne may also be analyzed as adverbs, specifically, whenever one of these two elements introduces a declarative root clause and directly precedes the finite verb. The latter approach is particularly common among researchers who hold to the long-standing assumption that Medieval French was a verb-second (V2) language, i.e. a language in which the finite verb immediately follows a constituent in sentence-initial position in a declarative clause. The attribution of the ability to induce subject-verb inversion to et and ne allows these researchers to reduce significantly the number of verb-first (V1) declarative root clauses, which are not very welcome under a V2 analysis of Medieval French. ${ }^{4}$

In this paper, we shall illustrate and compare different approaches to $e t$ and $n e$ and shall address some of the questions pertaining to their motivations and the evidence which has been offered in their favor, showing that the consistent approach proves to be empirically more adequate.

\section{The contexts of $e t$ and $n e^{5}$}

As for the occurrence of $e t$, one must distinguish several distributional contexts (Diez 1882: 1015f and 1058ff, Meyer-Lübke 1899: 802f, Tobler-Lommatzsch 1954: 1509-1517, Grevisse \& Goosse 2007: 297-306). Just as in Modern French, et is used as a coordinating conjunction to link words, phrases or clauses

3 One generally considers the following elements of Medieval French not to be (independent) constituents: clitic elements ('weak' object and adverbial pronouns as well as the 'weak' sentential negation particle $n e$ ) and the coordinating conjunctions car, mais, et, ni, and ou. Note that preverbal subject pronouns in Medieval French (still) represent constituents because of their non-clitic behavior.

4 In V2 languages, V1 declarative root clauses are restricted to a small number of very marked contexts (cf. Önnerfors 1997 for a discussion of V1 declarative root clauses in Germanic).

5 The discussion of the occurrence of $e t$ and $n e$ will be restricted to declarative root clauses since the questions addressed in this paper exclusively refer to these contexts. 


\section{Much Ado About Nothing? On the Categorial Status of et and ne in Medieval French}

with identical subjects. In addition, et may introduce a declarative root clause whose subject differs from that of the preceding one. A peculiarity of Medieval French is that in these constructions, the subject may not only precede the finite verb (1a-b) (referred to in the following by the construction type et$\mathrm{S}-\mathrm{V})$ but may also directly follow it (1c) (et-V-S). In the latter constructions, et, being optionally followed by clitic elements, directly precedes the finite verb and the postverbal subject must be non-pronominal in nature. ${ }^{6}$ Additionally to these constructions, et may also introduce a declarative root clause, which is preceded by an embedded clause and whose subject is preverbal if expressed (1d-e) (clause-et-S-V). ${ }^{7}$

(1a) et mon seigneur Phelippe dit que [...]. ET le roy dit que [...] 'and Sir Philipp said that [...]. And the king said that [...]'

(Saint Louis, 387)

(1b) Lors me dit un de mes mariniers : [...]. ET je diz que je vouloie bien que [...]

'Then one of my mariners said to me: [...]. And I said that I would be quite happy if [...]'

(Saint Louis, 320)

(1c) Quant [...], il firent mettre en escrit le serement [..], ET disoit l'escript ainsi, que [...]

'When $[\ldots]$, they saw to it that the oath [...] was written down, and the written document read the following: [...]'

(Saint Louis, 362)

6 There is one general exception to this restriction, to wit the indefinite subject pronoun on 'one, they'. This seemingly anomalous behavior of on may be accounted for in terms of its (persisting) nominal qualities, given that it stems from the nominal ome (< Latin homo 'man'). Postverbal subject pronouns other than on are extremely rare; to our knowledge, only seven such examples are reported in the literature for the entire Medieval French period (Philippsthal 1886: 11, Foulet 1928: 287, Bergh 1952: 47, Skårup 1975: 242).

7 In the examples illustrated in this paper, elements are highlighted according to the following conventions: SMALL CAPS $=e t$ or $n e$; bold = subject; italic $=$ finite verb; underlined $=$ constituents preceding the finite verb; dotted line $=$ non-constituents preceding the finite verb. 
(1d) Quoi que li feste estoit plus plaine, ET Aucassins $f u$ apoiiés a une puie tos dolans et tos souples.

'While the party was in full swing, Aucassin, all sad and downcast, leaned against a balustrade.'

(Aucassin 20, 15-16)

(1e) Et puis qu'il est issi que vos me desfiés, ET je me garderai

'And because you are challenging me, I will take care of myself'

(RMont 289, $30^{8}$ )

Regarding $n e$, one must distinguish between two ne elements, specifically, the coordinating conjunction $n e$ and the sentential negation particle ne. The coordinating conjunction, which increasingly shows up as $n i$ from the first fourth of the $13^{\text {th }}$ century, stems from Latin nec 'and not' and combines words, phrases or clauses (Diez 1882: 1061, Buridant 2000: 555). As for the sentential negation particle, it is generally considered to be an atonic clitic element. In contrast to Modern French, it is inherently negative and therefore suffices to express sentential negation by itself (Bachmann 1914: 76, Raynaud de Lage 2004: 237). In declarative root clauses, ne always occurs before the finite verb, being itself optionally preceded by clitic pronouns, and may either be preceded by one or several constituents (2a-b) (referred to in the following by the construction type S-ne-V) or introduce the clause itself (2c). In the latter construction, the subject directly follows the finite verb, is different from the subject of the preceding declarative root clause, and is always non-pronominal in nature. $^{9}$

8 This example represents a quotation from Tobler \& Lommatzsch (1954: 1515) taken from: Renaus de Montauban. Ed. by H. Michelant. Stuttgart 1862.

9 As in the case of $e t$, the indefinite subject pronoun on represents a general exception to this restriction (Skårup 1975: 251ff). One may account for this in the same way as for the corresponding constructions with et (see footnote 6). To our knowledge, only five examples with postverbal subject pronouns other than on are reported in the literature for the entire Medieval French period (Reid 1939: 310, Kattinger 1971: 7, Skårup 1975: 242). 


\section{Much Ado About Nothing? On the Categorial Status of et and ne in Medieval French}

(2a) La traisun NE poet estre celee ;

'The treason cannot be concealed;'

(Roland, 1458)

(2b) ․ Jo NE yos vei, veied vus Damnedeu!

'I do not see you, may God see you!'

(Roland, 2004)

(2c) Nostre Franceis [...] Enfüerunt en aitres de musters ; N'en mangerunt ne lu ne porc ne chen $»$.

'Our Frenchmen [...] will bury us in church graveyards; Neither wolves nor pigs nor dogs will eat from it".'

(Roland, 1746-1751)

Note that Medieval French disposes of a further negation element, non. This tonic element may occur either in sentences without a verb, before present participles and infinitives or in answers and negative resumptions when preceding the finite forms of the verbs estre, avoir, valoir as well as the substitutional verb fere (Diez 1882: 1060, Huguet 1894: 260f, Darmesteter 1897: 206f, Raynaud de Lage 2004: 236).

\section{On the categorial status of $e t$ and $n e$}

\subsection{On the status of et}

From a purely descriptive point of view, a choice between two assumptions about the categorial status of the element et imposes itself. Either one assumes that there is only one et in Medieval French, irrespective of the syntactic contexts in which it occurs. Or one assumes that Medieval French has more than one et, depending on the syntactic context in which et appears. The first assumption implies an analysis of $e t$ as a coordinating conjunction and, consequently, as a non-constituent, i.e. an element which has no influence on word order. The second assumption entails the existence of a plurality of et, among which one or several of these are analyzed as constituents in addition to one such et analyzed as a coordinating conjunction. Thus, depending on the respective assumption one adopts, different analyses suggest themselves for $e t$ in a given distributional context. In fact, the respective assumption one adopts 


\section{ZIMMERMANN, G. A. KAISER}

is directly dependent on one's theoretical background. It is thus that different theoretical backgrounds may induce fundamentally different and, therefore, conflicting analyses of $e t$.

Among the various constructions featuring et, those illustrated in (1c) and (1d-e) are of particular interest here since they have actually led to conflicting syntactic analyses. As may be recalled, et-V-S constructions stand out due to the facts that (i) et directly precedes the finite verb and that (ii) the postverbal subject is non-pronominal in nature and differs from that of the preceding declarative root clause. Clause-et-S-V structures (i) start off with an embedded clause followed by et preceding an ensuing declarative root clause and (ii) have a preverbal subject, if expressed.

\subsubsection{The analysis of et in et- $V-S$ constructions}

In the wake of Thurneysen's (1892) seminal work on word order in Old French, traditional and generative researchers generally assume that Medieval French is a V2 language, i.e. a language in which the finite verb is (almost) always in second position in declarative root clauses and is preceded by either a subject or a non-subject constituent, inducing subject-verb inversion. In addition, most generative researchers of Medieval French have unanimously adopted Foulet's (1928: 313) crucial assumption that subject pronouns may be omitted when occurring postverbally.

Against this theoretical background, researchers adopting a V2 analysis for Medieval French see themselves confronted with the following theory-induced determinations of the categorial status of et (Lemieux 1992: 62):

The question of the status of et reveals itself to be crucial at the point where one must determine, among the set of et elements, those which have an influence on the omission or the postposition of the subject in sentence structure, i.e. those which have the status of a triggering element, to adopt a familiar expression [= analysis as constituents, MZ\&GAK], and those which are outside the clause proper [= analysis as non-constituents, MZ\&GAK]. The question is far from trivial, given that the analysis of these elements is partly 


\section{Much Ado About Nothing? On the Categorial Status of et and ne in Medieval French}

responsible for the preservation of the $\mathrm{V} 2$ character of the language. ${ }^{10}$

In this connection, it is not surprising that $e t-\mathrm{V}-\mathrm{S}$ constructions are given a syntactic analysis which differs from that of other constructions with et (e.g. Völcker 1882: 13 and 16, Thurneysen 1892: 297, Meyer-Lübke 1899: 803, Morf 1878: 208f, Büchsenschütz 1907: 11f, fn.1, Melander 1916: 85f, Foulet 1928: 287 and 310, Lerch 1934: 422f, Blasberg 1937: 12, Lewinsky 1949: 34 and 69, Dupuis, Lemieux \& Gosselin 1992: 281 and 296 fn.6, Hirschbühler 1995: 258, Joly 1998: 218 and 291, Goldbach 2007: 113, fn.73). While in all of the other distributional contexts, et is generally assigned the categorial status of a coordinating conjunction, in et-V-S constructions, et is analyzed as an adverb, inducing subjectverb inversion. As a prime example for such a V2 approach to et, we give the following lengthy quotation by Thurneysen (1892: 291f and 297), who is, among the researchers referred to, the one most explicit about the determination of the categorial assignments to $e t$ :

II. An element is inserted between an exordium [= sentence-initial constituent, MZ\&GAK] and the finite verb, when it constitutes:

1. a coordinating conjunction, which has no adverbial character. These are:

a) $e t$;

Exception: The verb may appear directly after et when the subject is identical to that of the preceding clause. The atonic pronouns remain before the verb. If the subject is expressed anew, it of course intervenes between $e t$ and the verb. Exceptions to II 1:

10 Our translation. The original reads:

La question du statut de $e t$ se révèle cruciale dès le moment où il faut déterminer, parmi l'ensemble des $e t$, ceux qui ont une influence dans la structure propositionnelle sur l'omission ou la postposition du sujet, c'est-à-dire ceux qui ont un statut de déclencheur, pour reprendre une terminologie familière, et ceux qui sont hors proposition. La question est loin d'être triviale, car l'analyse de ces éléments détermine en partie le maintien du caractère V2 de la langue. 


\section{ZIMMERMANN, G. A. KAISER}

$\alpha$. The conjunction si se (= sic) always has the verb immediately after it. The same is naturally true for the combination et si. $^{11}$ [our emphasis]

The coordinating conjunction et may violate rule II 1 by taking the verb after it even in those cases in which the subject is expressed; the latter then shows up postverbally. The reason for this was on one hand the example set by the almost synonymous conjunction si (II $1 \alpha$ ). On the other, this new construction was facilitated by the constructions (II 1 a), which had long since accustomed the ear to hear the verb directly linked with $e t .^{12}$ [our emphasis]

In the approach at issue, it seems that the two completely different categorial assignments to et, specifically, that of a coordinating conjunction and that of an adverb ${ }^{13}$, both derive

11 Our translation. The original reads:

II. Zwischen das Exordium und das Verbum finitum schiebt sich ein Satzglied ein, wenn jenes ist:

1. Eine beiordnende Conjunktion, die keinen adverbialen Charakter [...] hat. Solche sind:

a) $e t ;[\ldots]$

Ausnahme: Das Verbum kann direkt hinter et treten, wenn sein Subjekt dasselbe ist, wie das des vorhergehenden Satzes [...]. Die unbetonten Pronomina behalten ihren Platz vor dem Verbum [...]. Wird das Subjekt neu ausgesetzt, so tritt es natürlich zwischen et und das Verbum $[\ldots]$

Ausnahmen zu II 1 :

$\alpha$. Die Konjunktion si se (= sic) nimmt das Verbum immer unmittelbar hinter sich [...]. Natürlich auch die Verbindung et si [...].

12 Our translation. The original reads:

Die beiordnende [...] Conjunction [...] et [...] [kann] gegen Regel II 1 das Verbum auch dann direkt hinter sich nehmen, wenn das Subjekt ausgesetzt ist; dieses kommt dann hinter das Verbum zu stehen. Die Veranlassung war einerseits das Beispiel der nahezu gleichbedeutenden Conjunction si (II $1 \alpha$ ). Begünstigt wurde aber die Neubildung durch die Constructionen [(II 1 a)], die das Ohr längst daran gewöhnt hatten, das Verbum unmittelbar mit et [...] verbunden zu hören.

13 Thurneysen (1892) actually calls the et of et-V-S constructions a 'coordinating conjunction', despite his account of et in terms of the adoption of the syntactic properties and, thus, the categorial status of the adverbial si, which he misleadingly calls a 'conjunction'. Other proponents of this approach are, however, more explicit insofar as they 


\section{Much Ado About Nothing? On the Categorial Status of et and ne in Medieval French}

from the same theory-internal need, namely that to 'keep' the finite verb in second position. Given the V2 analysis for Medieval French, in et-S-V constructions such as in (1a-b), given here as (3a-b), as well as in et-X-V-S constructions such as (3c), et is assigned the categorial status of a coordinating conjunction and is thus considered to be a non-constituent to prevent the analysis of these constructions as verb-third (V3). In $e t-\mathrm{V}-\mathrm{S}$ constructions such as in (1c), given here as (3d), on the other hand, et is attributed the status of an adverbial constituent to avoid the analysis of these constructions as V1:

(3a) ET le roy dit que [...]

'And the king said that $[\ldots]$ '

(Saint Louis, 387)

(3b) ET je $d i z$ que je vouloie bien que [...]

'And I said that I would be quite happy if [...]'

(Saint Louis, 320)

(3c) ET lors parla frere Renaut de Vichiers [...]

'And then spoke Brother Renaut de Vichiers [...]'

(Saint Louis, 382)

(3d) ET disoit l'escript ainsi, que [...]

'and the written document read the following: $[\ldots]$ '

(Saint Louis, 362)

In accordance with this apparent predetermination of Medieval French word order, the different categorial assignments to et seem to follow concomitantly from the different positionings of the subject with respect to the finite verb.

This (apparent) arbitrariness of the approach at issue notwithstanding, there seems to be some empirical evidence in favor of the adverbial status of et in et-V-S structures. This categorial status has been accounted for mainly in terms of a possible influence of the adverb si, acting as a syntactic model, on et. As noted by Bergh (1952: 46 and 50), si and et often seem to be almost synonymous, given that in the Old French

refer to the et at issue as an adverb (e.g. Foulet 1928: 287 and 310, Joly 2007: 218 and 291). 


\section{ZIMMERMANN, G. A. KAISER}

Fragments de Valenciennes, a translation from Latin, Latin et is at times rendered in Old French as si and that in different manuscripts of one and the same Old French text, one sometimes finds $e t$ in one manuscript and $s i$ in another. Also, one may consider the sequence $e t$ si to have encouraged the parallel behavior of si and et. As hinted at by Bergh (1952: 50), one may additionally appeal to the Tobler-Mussafia law established for Old Romance (Tobler 1912: 399f, Mussafia 1886: 255), according to which preverbal atonic clitic pronouns are disallowed when the verb is in first position. In this connection, the observation that et may be directly followed by an object clitic pronoun, as illustrated in (4), seems to support the categorial assignment of an adverb to $e t$.

(4a) ET s'sen ala li emperieres fuiant ... 'and the emperor fled ...'

(Conquête, 243)

As an alternative to this inconsistent approach to $e t$, it has been proposed that Medieval French disposes of just one et, interpreted as a coordinating conjunction, i.e. a non-constituent, having no influence on word order. The first to do so explicitly was Krüger (1876: 36), who puts forward the following assumption:

In Old French, the postposition of the subject could occur after every verb, even after transitives, whenever it introduces the proposition; coordinating conjunctions are not involved:

ET assemblerent li baron et li dux de Venise en un palais $[=$ And the barons and the dukes of Venice gathered in a palace]. ${ }^{14}$ [our emphasis and constituent highlighting]

As follows from the quotation, proponents of this alternative approach rule out the ability of $e t$ to induce subjectverb inversion. Among these proponents, Bergh (1952) is the

14 Our translation. The original reads:

Im Altfranzösischen [...] konnte nach jedem Verb, auch dem transitiven, sobald es den Satz einführte, Umstellung des Subjects erfolgen; coordinirende Conjunctionen [...] kommen dabei ausser Betracht: [...] Et assemblerent li baron et li dux de Venise en un palais. 


\section{Much Ado About Nothing? On the Categorial Status of et and ne in Medieval French}

first to discuss this issue in detail and provide empirical evidence in favor of a consistent interpretation of et as a coordinating conjunction. In fact, he does so by arguing against the analysis of $e t$ as an adverb in $e t-\mathrm{V}-\mathrm{S}$ constructions. As an initial observation, Bergh (1952: 46) notes that the Old French translator of the Fragments de Valenciennes at times renders Latin $e t-\mathrm{V}-\mathrm{S}$ constructions either as $e t-\mathrm{S}-\mathrm{V}$ structures or as $\mathrm{X}$ $\mathrm{V}-\mathrm{S}$ structures, in which et is replaced by $s i$ or dunc. Note in this connection also the observation by Büchsenschütz (1907: 11f, fn.1) that in Old French, in which the alleged syntactic model si is not yet in the process of being driven out by et, et$\mathrm{V}-\mathrm{S}$ constructions are already frequent. Regarding the sequence et si, Bergh (1952: 50) argues against any possible 'amplifying effect', claiming that the occurrence of this sequence is actually by far less frequent than that of its components, et and si.

With respect to the alleged need for the categorial assignment of an adverb to $e t$ in the context of preverbal clitic pronouns, he points out that these pronouns may also show up after the coordinating conjunction $\mathrm{ou}$ as well as in absolute sentence-initial position. In fact, in the light of the observation that the Tobler-Mussafia law ceased to be productive starting at the beginning of the $13^{\text {th }}$ century (Foulet 1928: 118, de Kok 1985: 90ff, Goldbach 2007: 110ff), as illustrated in (5), there is no need to analyze et in $e t-\mathrm{V}-\mathrm{S}$ constructions as an adverb.

(5a) Ba! Me connissiés vos ? fait Aucassins.

'Well! Do you know me? said Aucassin.'

(Aucassin, 24, 34)

(5b) ș'esmut lors li emperieres henriz [...]

'Then the emperor Henry set off [...]'

(Conquête, 443)

Moreover and more generally, Bergh (1952: 51) calls into question the alleged adverbial status of et in et-V-S constructions by pointing out that this would imply that the Medieval French coordinating conjunction $e t$, which had originally been an adverb in Latin, would be reverting to its status as an adverb. Note also that irrespective of any semantic similarity of $e t$ and $s i$, one wonders why it is si which should act as a syntactic 


\section{ZIMMERMANN, G. A. KAISER}

model for $e t$, and not the reverse. In fact, si appears mainly as an adverb and is only occasionally used as a coordinating conjunction while et (almost) always occurs as a coordinating conjunction. Against this backdrop, one would rather expect $s i$ to behave syntactically like $e t$ if the former takes on the role of the latter (Vance 1993: 298f).

Furthermore, Bergh (1952: 51) emphasizes the fact that while subject-verb inversion is obligatory after si, it is not so after $e t$, as illustrated in (3). In fact, as pointed out by Herman (1954: 365), subject-verb inversion after $e t$ is a rather infrequent phenomenon. Given this as well as the observation that declarative root clauses introduced by et are by far more numerous than those introduced by si, Herman notes that it should rather be $e t$ which should act as a syntactic model for $s i$, and not the reverse. Still, Herman rejects the possibility of any analogy, arguing that et and si crucially differ insofar as et is always atonic while $s i$ is always tonic. What also distinguishes si from et is, according to Bergh, the fact that in constructions with $s i$, postverbal subject pronouns other than on are possible, contrary to constructions with et. As pointed out by Vance (1993: 310), the alleged transfer of the inversion properties of $s i$ to $e t$ "fails to predict the absence of postverbal subject pronouns in this configuration [...], sacrificing empirical accuracy" (see also Baulier 1956). In particular, "in no case does an adverb trigger inversion of NP subjects but not pronouns" (Vance 1993: 291).

The following crucial observation put forward by Bergh (1952: 54f) also casts doubt on the categorial assignment of an adverb to $e t$ :

In Old French, the subject was inverted above all when occurring with verbs of saying but sometimes also in combination with the verb être 'to be' and intransitive verbs. This construction may be found in sentences beginning with the conjunction et just as well as in non-introduced sentences; the latter fact shows that the conjunction is not involved at all in the inversion of the subject. $^{15}$

15 Our translation. The original reads: 


\section{Much Ado About Nothing? On the Categorial Status of et and ne in Medieval French}

To this may be appended the observation that in declarative root clauses, subject personal pronouns are generally omitted not only in those cases in which the finite verb is preceded by et but also in those cases in which the finite verb is in absolute sentence-initial position.

Before turning to the discussion of clause-et-S-V constructions, we quickly tackle what we call an 'in-between' approach proposed for $e t-\mathrm{V}-\mathrm{S}$ structures (Lemieux 1992, Vance 1993, Lemieux \& Dupuis 1995). What is common to these proposals, which also take Medieval French to be V2, is that et is always analyzed as a non-constituent. Still, theory-internally, these proposals put forward the assumption that there are in fact two et constructions, which differ from each other in terms of their respective syntactic structures.

Lemieux (1992: 59) and Lemieux \& Dupuis (1995: 97) suggest that Middle French disposes of two et elements, a "coordinating particle" and a "discursive element". They claim that the latter, just like other discourse elements (or, mais, ni), is inserted into the head of a left-peripheral projection called 'Assertion phrase' or ' $\Sigma$-phrase' and may allow for the licensing of an empty expletive subject pronoun in the ensuing projection, "giving the sentence the verb-second interpretation" (Lemieux \& Dupuis 1995: 98).

For Vance (1993: 295 and 299), et is always a coordinating conjunction. Still, depending on the respective construction with $e t$, i.e. whether a given $e t$ construction is "syntactically independent from the subject of the preceding clause" (Vance 1993: 287) or not, she assumes two different syntactic structures. In the light of the anomalous absence of postverbal subject personal pronouns in constructions with $e t$, she proposes to analyze these constructions as truncated propositions. In fact, Vance (1993: 299f) argues that these "are not ordinary matrix clauses but are dependent on the preceding matrix clause even

[...] en ancien français le sujet était inverti surtout avec les verbes déclaratifs mais parfois aussi avec être et les verbes intransitifs. Cette construction pouvait se rencontrer dans des phrases débutant par la conjonction et aussi bien que dans des phrases non introduites, ce qui montre que la conjonction n'y était pour rien. 


\section{ZIMMERMANN, G. A. KAISER}

though they have their own subject (null or overt) and inflected verb". Note that, to our knowledge, this analysis represents the first account for the general non-occurrence of postverbal subject personal pronouns in et-V-S constructions.

To summarize, the preceding discussion of the different approaches to the categorial status of $e t$ in $e t-\mathrm{V}-\mathrm{S}$ constructions has shown that there exists evidence for each of these approaches. A careful consideration of all the evidence presented indicates, however, that the inconsistent approach faces several major drawbacks and reveals itself to be least compelling. While avoiding several of the problems associated with the latter approach, the in-between approach still shares some of the shortcomings pertaining to the inconsistent approach. In particular, the assignment of the syntactic structures associated with et appears to be arbitrary insofar as it simply follows from the respective positioning of the subject and / or its coreferentiality with the subject of the preceding clause. Against this backdrop, the consistent approach is the one most in line with the data and thus represents the most compelling approach to et in et-V-S constructions.

\subsubsection{The analysis of et in clause-et- $S$-V constructions}

We will now briefly have a look at clause-et-S-V structures, since these have also led to conflicting syntactic analyses. So far, these structures have been given little consideration in the literature. Diez (1882: 1016) considers et to alternate with the adverb $s i$ in this type of construction. In fact, he analyzes both elements as "particles" and claims that they have the same meaning, 'then' (see also Foulet 1928: 287). This approach implies the analysis of et as a (temporal) adverb and thus as a constituent (see also Raynaud de Lage 2004: 222, Buridant 2000: 553f). According to this approach, the constructions at issue would give verb-fourth structures.

On the other hand, Koopmann (1910: 86) and Bartsch (1920: 418) consider the et at issue to be semantically empty, i.e. an "explétif", to which is attributed the sole function of introducing the ensuing declarative root clause. From its semantically empty nature, it follows that this et is not assigned 


\section{Much Ado About Nothing? On the Categorial Status of et and ne in Medieval French}

the status of a constituent. Consequently, clause-et-S-V constructions are given the analysis of V3 structures.

While the two opposing approaches just outlined have in common that they both refrain from assigning et the categorial status of a coordinating conjunction, they differ with respect to the interpretation of $e t$. In the light of the observation that in constructions consisting of an embedded clause followed by a declarative root clause, the use of $e t$ as an 'introductory element' is relatively rare while that of the adverb si is highly frequent, one may assume that et may have actually inherited the semantics of si. If this is correct, the semantic proposal by Diez (1882) seems to be on the right track. Still, given that in contrast to $s i$, subject-verb inversion is never reported after $e t$ in the construction at issue, it seems reasonable to assume that $e t$ retains its categorial status as a coordinating conjunction. This alternative approach is related to the proposal put forward by Ebering (1881: 344), who argues for the analysis of et as a coordinating conjunction (see also Moignet 1976: 331) while rejecting any semantic influence of the adverb si on et. In fact, he even claims that $s i$ in the constructions at issue is no longer a (full) adverb but has "coordinating" force.

\subsection{On the status of ne in ne- $V-S$ constructions}

The sentential negation particle ne may occur in a similar syntactic context as et in et-V-S constructions, namely in $n e-\mathrm{V}$ $\mathrm{S}$ constructions. The latter stand out due to the fact that (i) ne directly precedes the finite verb, and that (ii) the postverbal subject is non-pronominal in nature and differs from that of the preceding declarative root clause.

Like $e t$-V-S constructions, $n e-\mathrm{V}-\mathrm{S}$ constructions principally allow for two different and opposing analyses of the categorial status of $n e$. Either $n e$ is given the same analysis in $n e-\mathrm{V}-\mathrm{S}$ constructions as that for $\mathrm{S}-n e-\mathrm{V}$ constructions, i.e. the status of an atonic clitic particle, or it is assigned the categorial status of a tonic non-clitic adverbial constituent. Note that while under the former analysis ne does not have any influence on word order, it does so under the latter. Against this backdrop, then, the crucial question thus is whether the sentential negation particle ne is assigned one single category or two different ones. 


\title{
M. ZIMMERMANN, G. A. KAISER
}

As in the case of $e t$, the answer to this question depends on the theoretical background of the researcher.

It is not surprising that mainly in connection with the analysis of Medieval French as a V2 language, researchers (e.g. Völker 1883: 13, Ellinger 1886: 6, Koopmann 1910: 51, Büchtemann 1912: 13, Herman: 1954: 91, fn.3, Falk 1969: 241, Skårup 1975: 254, Lukaszewicz 1979: 58, Hirschbühler 1995: 258, Vance 1997: 236) have analyzed ne similarly to et insofar as they argue for an "ambivalent" nature of ne which is "sometimes" considered to be an atonic clitic element and "sometimes" a (more or less) tonic non-clitic adverb (Falk 1969: 235, fn.3). We give the following quotation from Franzén (1939: 63f) who illustrates this state of affairs for subject pronouns and assigns $n e$ an intermediate status:

\begin{abstract}
$\mathrm{Ne}$ (non) is often placed at the beginning of the sentence. We are tempted to consider this construction to be identical to that which presents itself when a complement with an accent of its own is in sentence-initial position. On the other hand, when the subject pronoun is expressed, ne no longer has the same influence on sentence structure as a complement with an accent of its own appearing before the verb. The negation ne is not capable of inducing the inversion of the subject pronoun. ${ }^{16}$
\end{abstract}

Similar to the corresponding analyses for $e t$, we are confronted here with an approach which implicitly argues for two different types of $n e$ and which is driven by the same theory-internal need, namely that of allowing for the occurrence of the finite verb in second position. To illustrate, in S-ne-V constructions such as in (2a-b), given here as $(6 a-b)$, as well as

\section{Our translation. The original reads:}

$N e$ (non) est souvent placé en tête de la phrase [...]. Nous sommes tentés de regarder cette construction comme identique à celle qui se présente, quand un complément à accent propre se trouve en tête de la phrase [...]. D'autre part, si le pronom sujet est exprimé, ne n'exerce plus, sur la structure de la phrase, la même influence qu'un complément à accent propre devant le verbe. [...] La négation ne n'est pas capable d'entraîner l'inversion du pronom sujet. 


\section{Much Ado About Nothing? On the Categorial Status of et and ne in Medieval French}

in $\mathrm{X}-n e-\mathrm{V}-\mathrm{S}$ constructions such as (6c), ne is interpreted as an atonic clitic element and is thus considered to be a nonconstituent to prevent the analysis of these constructions as V3. In $n e-\mathrm{V}-\mathrm{S}$ constructions such as in (2c), given as (6d), however, $n e$ is interpreted as a (more or less) tonic adverb to avoid the analysis of these constructions as $\mathrm{V} 1:^{17}$

(6a) La traisun NE poet estre celee ;

'The treason cannot be concealed;'

(Roland, 1458)

(6b) \ـ NE vos vei, veied vus Damnedeu !

'I do not see you, may God see you!'

(Roland, 2004)

(6c) Des les apostles NE fut hom tel prophete

'Since the apostles there was no such prophet'

(Roland, 2255)

(6d) N'en mangerunt ne lu ne porc ne chen ».

'Neither wolves nor pigs nor dogs will eat from it".'

(Roland, 1751)

In accordance with the apparent predetermination of Medieval French word order, these different interpretations of ne, which

17 Note that in the literature, it has been proposed that the sentential negation particle ne may also induce the inversion of the subject (or its omission) in constructions other than $n e-\mathrm{V}-\mathrm{S}$. These proposals, which amount to the analysis of $n e$ as a tonic non-clitic adverb, relate both to embedded clauses in which $n e$ follows the conjunction and precedes the finite verb such as (i) (Franzén 1939: 67, Kattinger 1971: 60, 66 and 121, Lukaszewicz 1979: 58, Hirschbühler \& Junker 1988: 68, Hirschbühler 1995: 270) and to declarative root clauses introduced by $n e$ which are preceded by an embedded clause as in (ii) (Koopmann 1910: 85, Kattinger 1971: 45, Skårup 1975: 256 and 270):

(i) Lessez les morz tut issi cun il sunt, Que N'ị adeist ne beste ne lion,

'Leave the dead all here just as they are so that neither an animal nor a lion may touch them,'

(Roland, 2335-2336)

(ii) quant an le vialt, NEl puet an fere.

'when one wants to do so, one cannot do it.'

(Yvain, 2528)

Given that the discussion in the text principally also holds for these types of construction, we will not go into them. 


\section{ZIMMERMANN, G. A. KAISER}

in fact represent two different categorial assignments, seem, as in the case with et, to follow concomitantly from the different positionings of the subject with regard to the finite verb.

All the same, one may conceive of independent evidence in favor of the existence of a (more or less) tonic adverbial $n e$. From the observation that in Medieval French, ne was (still) able to express negation by itself, one may infer that $n e$ disposes of tonic qualities. That $n e$ may indeed be tonic seems also to follow from Kattinger's (1971: 139f) syntactic analysis of the Old French text Erec et Enide. He observes with regard to $n e-\mathrm{V}-\mathrm{S}$ constructions that in almost all instances, the finite verb is a temporal or modal auxiliary, carrying but little meaning (see also Foulet 1928: 260, Moignet 1976: 277). From this he concludes that ne here "naturally" increases in tonicity and bears the main stress of the sentence.

What also seems to support the analysis of $n e$ as a tonic non-clitic element in $n e-\mathrm{V}-\mathrm{S}$ constructions is the observation that when followed by clitic object pronouns such as le, les, me, the latter amalgamate with $n e$, giving structures like nel $(=n e+l e)$, nes $(=n e+l e s)$ or $n e m(=n e+m e)$. This hints at the status of $n e$ as a host for clitic pronouns. In addition, interpolation structures like those in (7), in which a constituent intervenes between the sequence of $n e$ and a clitic pronoun and the finite verb, seem to provide further evidence for the nonclitic nature of ne (Hirschbühler \& Junker 1988: 73):

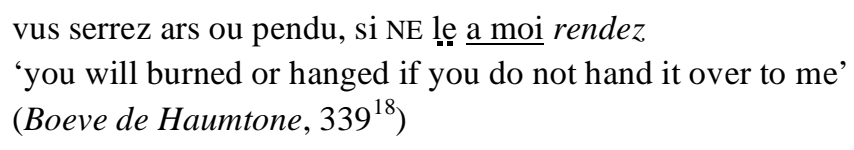

Another observation which seems to support the analysis of ne as an adverb comes from Skårup (1975: 392). Implicitly appealing to the Tobler-Mussafia law, he points out that in Old French, the $n e$ at issue is never followed by a finite verb with postverbal clitic object pronouns. In a similar vein, Foulet (1928: 322f) observes

18 This sentence represents a quoted example from Skårup (1975: 16) taken from: Der anglonormannische Bueve de Haumtone. Ed. by A. Stimming. Halle $1899,133$. 


\section{Much Ado About Nothing? On the Categorial Status of et and ne in Medieval French}

that $n e$ allows for the preverbal positioning of clitic object pronouns in negative imperatives, as illustrated in (8):

(8) 'NE me tient si.

"Do not think of me like that.'

(Livre Reis, p.5)

Alternatively, it has been proposed that irrespective of its syntactic context, the sentential negation marker ne represents an atonic clitic particle, having no influence on word order. To our knowledge, Büchsenschütz (1907: 38f and 87ff) is the only researcher who explicitly argues in favor of such a consistent analysis. Unfortunately, he does not provide independent evidence to support his approach.

Nevertheless, as with the corresponding constructions with $e t$, there is evidence supporting such a consistent approach. First, as may be recalled, preverbal clitic object pronouns may also occur in absolute sentence initial position in Medieval French, given that the Tobler-Mussafia law ceases to be productive in Old French. Also, instances of interpolation as in (7), which would possibly support the analysis of $n e$ as a nonclitic adverb, are virtually inexistent in Medieval French. To our knowledge, the sentence provided by Hirschbühler \& Junker (1988) represents the only example in the relevant literature (see also Skårup 1975: 16).

What is more, even though ne may express sentential negation on its own during the entire Medieval French period, it may be accompanied by a negative adverb like mie or pas from very early on (Moignet 1976: 277):

(9a) Dient paien: « Nus NE`1 susfrirum mie!

'The pagans say: "We cannot stand this any longer!'

(Roland, 1615)

(9b) «Sire, je NE m’acorde pas a cest conseil ».

"'Sire, I do not agree with this opinion".'

(Saint Louis, 319)

This accompaniment, which is generally held to result from the need to emphasize sentential negation (Diez 1882: 1084, 


\section{ZIMMERMANN, G. A. KAISER}

Jespersen 1917: 7), hints at the development of the $n e$ at issue into an atonic clitic particle.

Another observation in favor of this analysis is the fact that while adverbs, which are generally held to induce subjectverb inversion when occurring in sentence initial position, allow for postverbal subject pronouns other than on, this is not true for $n e$. Given that the same holds for $e$, one may again appeal to Vance's (1993) observation that this state of affairs would represent an anomalous exception.

Also, as noted above in connection with et, Medieval French features constructions with the finite verb in absolute sentence initial position directly followed by the subject. From this it follows that $n e$ is not (necessarily) involved in subjectverb inversion. Note again that the V1 constructions at issue are identical to the constructions with $n e$ (as well as to those with $e t$ ) insofar as subject personal pronouns are inexistent.

In addition to the inconsistent and consistent approaches to $n e$ just outlined, an 'in-between' approach, similar to the corresponding structures with et, is proposed by Franzén (1939: 63ff). Assuming that $n e$ lost its tonicity in the preliterary period of French, he argues for the simultaneous existence of two constructions with $n e$, which he labels "traditional" and "new", respectively. While in the latter, which relate to S-ne-V constructions, ne is claimed to behave syntactically like an atonic clitic element, i.e. like a non-constituent, in the former, which relate to $n e-\mathrm{V}-\mathrm{S}$ constructions, $n e$ is assumed to have kept its syntactic properties from the (preliterary) time when it was a tonic adverbial.

To sum up, the preceding discussion of the categorial status of $n e$ in $n e-\mathrm{V}-\mathrm{S}$ constructions has shown that as in the case of et, three different approaches may be distinguished. While there is (some) independent evidence for the inconsistent and consistent approaches to the $n e$ at issue, there is no such evidence for the in-between approach. The latter approach also fails to be compelling because of its implausibility. In fact, such an approach implies the existence of two atonic sentential negation particles $n e$, which have a different syntactic status, to wit that of an atonic clitic element and that of a tonic non-clitic 


\section{Much Ado About Nothing? On the Categorial Status of et and ne in Medieval French}

adverb, respectively. In addition, the argumentation put forward to account for $n e-\mathrm{V}-\mathrm{S}$ constructions appears inconclusive insofar as Franzén (1939: 66f) appeals to the influence of frequency in two opposing and, hence, conflicting ways. Under this approach, the frequent usage of an element may result in a change of its categorial status without, however, inducing a change of its syntactic properties. Given the scarcity of independent evidence for the consistent and inconsistent approaches, it is quite difficult to tell which of these two approaches is most compelling. From the similarity of $n e-\mathrm{V}-\mathrm{S}$ constructions to $e t-\mathrm{V}-\mathrm{S}$ constructions as well as from a careful consideration of all the evidence presented for and against either of these two approaches, we conclude that the consistent approach proves to be most compelling.

\section{Conclusion}

The main purpose of this paper has been to draw attention to the categorial assignments to the two Medieval French elements et and $n e$, whose relevance for and impact on syntactic analyses may easily go unnoticed. As our discussion has shown, different approaches to the categorial status of these elements exist, and they principally consist of analyses either in favor of or against a consistent categorial assignment to et and ne, respectively. The existence of independent evidence for and against either of these approaches shows very well that the determination of the categorial status of these two elements is not straightforward and represents a challenge for any researcher who is confronted with the task of syntactically annotating a Medieval French text corpus. Moreover and more importantly, it could be shown that the categorial assignments to et and ne by annotators from different theoretical backgrounds may produce fundamentally differing and therefore conflicting analyses of these elements. This of course implies a reduced comparability of the results of the analyses of one and the same text as well as of different texts. Depending on the adoption of either a consistent or inconsistent approach, V1 declarative root clauses are either a (more) frequent or an infrequent feature of Medieval French. What is more, our discussion has shown that both inconsistent analyses, which argue for various categorial assignments to et 


\section{ZIMMERMANN, G. A. KAISER}

and $n e$, and what we have termed in-between analyses, which argue for a (more or less) consistent interpretation of $e t$ and ne while assigning each of them different syntactic structures, face several major drawbacks. In the light of this, we have suggested that a consistent analysis of $e t$ as a coordinating conjunction and $n e$ as an atonic clitic particle is more adequate, since it is more in line with the data.

\section{References}

Bachmann A. (1914). Die Sprache des François de La Noue. Borna-Leipzig : Noske.

Bartsch K. (1920). Chrestomathie de l'ancien français (VIII $X V^{e}$ siècles). Leipzig : Vogel, douzième édition entièrement revue et corrigée par Leo Wiese.

Baulier F. (1956). "Contribution à l'étude de l'inversion du sujet après la conjonction "et" », Le français moderne 24 : 249-257.

Bergh L. (1952). «Quelques réflexions sur l'inversion après la conjonction et en ancien et en moyen français », in Mélanges de philologie romane offerts à M. Karl Michaëlsson par ses amis et ses élèves. Göteborg : Bergendahl, 43-55.

Blasberg H. (1937). Die Wortstellung bei Montaigne. BochumLangendreer : Pöppinghaus.

Büchsenschütz C. (1907). Die Setzung des Personalpronomens als Subjekt in der altfranzösischen Übersetzung des Wilhelm von Tyrus. Halle : Kaemmerer \& Co.

Buridant C. (2000). Grammaire nouvelle de l'ancien français. Paris : Sedes.

Darmesteter A. (1897). Cours de Grammaire historique de la langue française. Quatrième partie : Syntaxe. Paris : Delagrave.

Diez F. (1882). Grammatik der romanischen Sprachen. Drei Theile in einem Bande. Bonn : Weber, fünfte Auflage.

Dupuis F., Lemieux M. \& Gosselin D. (1992). «Conséquences de la sous-spécification des traits de Agr dans l'identification de Pro », Language Variation and Change 3 : 275-299. 


\section{Much Ado About Nothing? On the Categorial Status of et and ne in Medieval French}

Ebering E. (1881). «Syntaktische Studien zu Froissart», Zeitschrift für romanische Philologie 5 : 323-376.

Ellinger J. (1886). «Syntax der Pronomina bei Chrestien de Troies », in W. Kukula (Hg.), Fünfzehnter Jahresbericht über die K. K. Oberrealschule, in dem II. Bezirke von Wien. Wien: Verlag der K. K. Oberrealschule im II. Bezirke, 3-35.

Falk P. (1969). « Particularisme des propositions imperson-nelles en ancien français », Studia Neophilologica $41: 235-252$.

Foulet L. (1928). Petite syntaxe de l'ancien français. Paris : Champion, troisième édition revue. Réédition 1982.

Franzén T. (1939). Etude sur la syntaxe des pronoms personnels sujets en ancien français. Uppsala : Almqvist \& Wiksell.

Goldbach M. (2007). Pronominalisierung der Infinitivkomplemente im Alt- und frühen Mittelfranzösischen und im Altitalienischen. Frankfurt/Main : Lang.

Grevisse M. \& Goosse A. (2007). Le bon usage. Grammaire française. Bruxelles : De Boek \& Larcier, $14^{\mathrm{e}}$ édition.

Herman J. (1954). «Recherches sur l'ordre des mots dans les plus anciens textes français en prose », Acta Linguistica Academiae Hungaricae 4: 69-94, 351-382 ; reprinted in J. Herman (1990), Du latin aux langues romanes. Etudes de linguistique historique (réunies par Sándor Kiss). Tübingen : Niemeyer, 234-288.

Hirschbühler P. (1995). « Null subjects in verb-first embedded clauses in Philippe de Vigneulles' Cent Nouvelles Nouvelles », in A. Battye \& I. Roberts (éd.), Clause Structure and Language Change. New York: Oxford University Press, 257-291.

Hirschbühler P. \& Junker M.-O. (1988). «Remarques sur les sujets nuls en subordonnées en ancien et en moyen français », Revue québécoise de linguistique théorique et appliquée $7: 63-84$.

Huguet E. (1894). Etude sur la syntaxe de Rabelais comparée à celle des autres auteurs prosateurs de 1450 à 1550. Paris / Genève : Slatkine; réimpression 1967. 
Jespersen O. (1917). Negation in English and other languages. Københaven : Høst \& Søn.

Joly G. (1998). Précis d'ancien français. Paris : Colin.

Kattinger G. (1971). Die Verwendung des Personalpronomens als Subjekt zum Verbum dargestellt an Erec und Enide von Chrétien de Troyes. Nürnberg : Dissertation.

Kok A. de (1985). La place du pronom personnel régime conjoint en français. Une étude diachronique. Amsterdam: Rodopi.

Koopmann W. (1910). Die Inversion des Subjekts im Französischen. Göttingen : Dieterichsche Univ. Buchdruckerei.

Krüger P. (1876). Über die Wortstellung in der französischen Prosaliteratur des dreizehnten Jahrhunderts. Berlin: Schettler.

Lemieux M. (1992). «Et dans les constructions à sujet nul et à sujet postposé en moyen français », Travaux de linguistique $25: 59-75$.

Lemieux, M. \& Dupuis F. (1995). «The locus of verb movement in non-asymmetric verb-second languages: the case of Middle French », in V. Battye \& I. Roberts (eds), Clause Structure and Language Change. New York: Oxford University Press, 80-109.

Lerch E. (1934). Historische französische Syntax. Dritter Band: Modalität (Stimmführung und affektische Verkürzung; Interjektionen und Nominalsätze; Stimmdruck und Wortstellung). Leipzig : Reisland.

Lukaszewicz E.T. (1979). Les pronoms personnels sujets et l'impersonnel il en ancien français. Ph.D. dissertation. Montréal : McGill University.

Melander J. (1916). Etude sur magis et les expressions adversatifs dans les langues romanes. Upsal : Alquist \& Wiksel.

Meyer-Lübke W. (1899). Romanische Syntax. Leipzig : Reisland.

Morf H. (1878). Die Wortstellung im altfranzösischen Rolandsliede. Strassburg : Trübner. 


\section{Much Ado About Nothing? On the Categorial Status of et and ne in Medieval French}

Mussafia A. (1886). «Una particolarità sintattica della lingua italiana dei primi secoli », in G.I. Ascoli et al. (éd.), Miscellanea di filologia e linguistica. In memoria di Napoleone Caix e Ugo Angelo Canello, Firenze: Successori Le Monnier, 255-261.

Önnerfors O. (1997). Verb-erst-Deklarativsätze. Grammatik und Pragmatik. Stockholm : Almqvist \& Wiksell.

Philippsthal R. (1886). Die Wortstellung in der französischen Prosa des 16. Jahrhunderts. Halle : Plötz.

Raynaud de Lage G. (2004). Introduction à l'ancien français. Paris : Sedes, $2^{\mathrm{e}}$ édition, revue et corrigée. Nouvelle édition par Geneviève Hasenohr.

Reid T.B. (1939). «Non, nen and ne with finite verbs in French », in Studies in French Language and Medieval Literature presented to Mildred K. Pope by Pupils, Colleagues and Friends. Manchester : University Press, 305-313.

Skårup P. (1975). Les premières zones de la proposition en ancien français. Essai de syntaxe de position. København : Akademisk.

Thurneysen R. (1892). "Zur Stellung des Verbums im Altfranzösischen », Zeitschrift für romanische Philologie $16: 289-307$.

Tobler A. (1912). « Rezension von Jules Le Coultre, De l'ordre des mots dans Chrestien de Troyes, Dresden $1875 »$, in Tobler A., Vermischte Beiträge. Der vermischten Bei-träge zur französischen Grammatik fünfte Reihe. Leipzig: Hirzel, 395-415.

Tobler-Lommatzsch (1954). Altfranzösisches Wörterbuch. Adolf Toblers nachgelassene Materialien, bearbeitet und herausgegeben von Erhard Lommatzsch. Dritter Band. Wiesbaden : Steiner.

Vance B.S. (1993). «Verb-first declaratives introduced by et and the position of pro in Old and Middle French », Lingua 89 : 281-314.

Vance B.S. (1997). Syntactic Change in Medieval French. Verb-Second and Null Subjects. Dordrecht : Kluwer. 
Völcker B. (1882). Die Wortstellung in den ältesten französischen Sprachdenkmälern. Heilbronn : Henninger.

\section{Medieval French editions consulted}

Aucassin: Aucassin et Nicolette. Edition critique. Chronologie, préface, bibliographie, traduction et notes par J. Dufournet. Paris : Flammarion, deuxième édition revue et corrigée 1984.

Conquête: J. de Vileharduyn. La conqueste de Costentinoble d'après le manuscrit $n^{0} 2137$ de la B.N. Nancy : Centre de Recherches et d'Applications Linguistiques, Université de Nancy II 1978.

Roland: $\quad$ La Chanson de Roland. Edizione critica a cura di C. Segre. Milano : Ricciardi 1971.

Saint Louis: Joinville. Vie de saint Louis. Texte établi, traduit, présenté et annoté avec variantes par J. Monfrin, Paris: Dunod 1995.

Livre Reis: Li Quatre Livre des Reis. Die Bücher Samuelis und der Könige in einer französischen Bearbeitung des 12. Jahrhunderts. Nach der ältesten Handschrift unter Benutzung der neu aufgefundenen Handschriften kritisch herausgegeben von E.R. Curtius, Dresden: Gesellschaft für Romanische Literatur 1911. 